\title{
RELATIONSHIPS OF INFORMATION AND COUNSELING CENTER, KNOWLEDGE OF REPRODUCTIVE HEALTH, AND SEXUALLY COMPREHENSIVE EDUCATION IN ADOLESCENTS
}

\author{
Izdihar Azzah Paramastri, Izzatul Arifah
}

Faculty od Health Sciences, Universitas Muhammadiyah Surakarta

\begin{abstract}
Background: Sexual and reproductive health problems in adolescents are a high burden worldwide. However, they had limited access to reproductive health information center services. World Health Organization considers adolescents-friendly services when every obstacle hindering adolescents to receive sexual and reproductive health are being cleared. The main characteristics of adolescent-friendly reproductive health services are (1) accessible, (2) acceptable, (3) equitable, (4) appropriate, and (5) effective. The study objective was to investigate relationships of information and counseling centers, knowledge of reproductive health, and sexually comprehensive education in adolescents. Subjects and Method: A cross sectional study was carried out at two Senior High Schools in Sukoharjo, Central Java, in April 2019. A sample of 360 students was selected randomly. The dependent variable was knowledge on the reproductive health and sexual comprehensive. The independent variable was youth information and counseling center availability. The data were collected by questionnaire and analyzed by independent $\mathrm{t}-$ test.

Results: Mean of knowledge on the reproductive health and sexual comprehensive in students who study at school that provide youth information and counseling center (Mean=17.82; $\mathrm{SD}=3.15$ ) was higher than those who study at school without youth information and counseling center (Mean=16.16; $\mathrm{SD}=3.39)$, with $\mathrm{p}<0.001$.

Conclusion: Youth information and counseling center at school improves knowledge on the reproductive health and sexual comprehensive in senior high school students.

Keywords: youth information and counseling center, knowledge, reproductive health, sexual comprehensive, senior high school students

\section{Correspondence:}

Izdihar Azzah Paramastri. Faculty od Health Sciences, Universitas Muhammadiyah Surakarta. Jl. A. Yani Tromol Pos I, Pabelan. Email: astizdihar@gmail.com. Mobile: +6285707838939 .
\end{abstract}

